\title{
The Practices of HRM in Commercial Banks in India
}

\author{
Dr Jai Prakash Tripathi ${ }^{1}$, Ms. Harshita Bhatnagar ${ }^{2}$ \\ ${ }^{I}$ Dean, MBA, Sri Satya Sai University of Technology \& Medical Sciences, Sehore \\ ${ }^{2}$ Sri Satya Sai University of Technology \& Medical Sciences, Sehore
}

\begin{abstract}
Indian Banking industry must advance a human asset administration framework consistently and receive human asset improvement strategies that fit the requirements of the business. The Indian Banking industry must be overseen by saving money experts with a specific end goal to be focused and to get the products of the area in the global market. This paper concentrates a survey of HR administration hones in the saving money segment in India especially in Public Sector Banks with thought of five critical markers of managing an account segment, for example, work investigation, enlistment and determination, preparing and improvement, execution evaluation and pay. Therefore, the recommendations will bolster appropriate ramifications of HR administration hones in the Indian open division banks.
\end{abstract}

Keywords: HRM Practices, Public Sector Banks, Recruitment, Selection and Performance Appraisal

\section{Introduction}

At present, Indian managing an account segment is confronting wide assortment of chances and the splendid future situation. The changing monetary situation, spoke to by fast procedure of globalization has drawn out every one of the countries of the world together, without topographical limits for exchange and trade however with extraordinary measure of work open doors for people. Because of quick progression in data innovation and media transmission in the current years, the managing an account industry has been experiencing fast changes, mirroring various continuous change forms. In any case, there are sure issues in the Indian Banking framework, which require extraordinary consideration. A portion of the significant issues are:

- Continuous amassing of quagmire, which hampers the gainfulness of the banks.

- Accumulation of Non-Performing Assets (NPAs), which debilitates capital sufficiency and ceaseless solidness of banks.

- Some of people in general segment banks are confronting substantial over staffing, which decreases profitability of the banks.

Over all these require an extreme change in the enlistment, preparing, arrangement and advancement strategies of the banks. Along these lines, the primary concern is the way to expel legacies of the past and meet the requests and difficulties of the new period.

\section{HR Management Practices}

HR administration rehearses assume an extremely key part in accomplishing the association's objectives and keep up the upper hand. HRM hones allude to hierarchical exercises coordinated at dealing with the pool of human asset and guaranteeing that the assets are utilized towards the satisfaction of authoritative objectives (Schuler and Jackson 1987). Human asset administration practices is the administration of individuals inside the interior condition of associations, contains the exercises, approaches, and hones required in arranging, getting, creating, using, assessing, keeping up, and holding the suitable numbers and expertise blend of workers to accomplish the association's destinations (Appelbaum 2001). By and by associations are contending through actualizing the one of a kind HRM rehearses and because of the globalization associations receive the most a la mode HRM hones with a specific end goal to finish the hierarchical objectives. Best HRM practices are beneficial for both worker and business; it assumes a vital part in helpful development of the association. Keeping in perspective of HRM practices, it is comprehended that the HRM did not has coordinate part in business improvement but rather was more worried with unified enlistment to staff. In this specific circumstance, the survey of the review covers the accompanying most essential pointers of HR practices, which were trailed by any open area bank.

\section{Work examination}

Work examination includes gathering data about the qualities of an occupation utilizing one of a few strategies: perception, talking, surveys, or more specific employment investigation techniques, for example, position or practical investigation. Associations once in a while utilize a mix of occupation investigation strategies (Hawthorne, 2004; Mathis and Jackson, 1997). All the Banking experts detailed that they take after a blend of a few techniques for occupation examination of the representative. 


\section{Enlistment and choice}

Open Sector Banks takes after orderly strategy in enrollment and determination exercises. For Recruitment and Selection these banks takes after some standard a large portion of the cases. The honed game plan for determination and enrollment is the corporate choose what positions should fill and how to fill the prompt and future prerequisites. This aggregate method is intended to cover all positions from base to top level.

Indian Public Sector Banks utilize both strategies for enlistment i.e., inner and outside business sectors. As a rule, for administrative and officer posts, outer market is utilized through publicizing and so forth. Then again, the administrative/official positions are topped off through advancements and exchanges i.e., for higher positions the inward market is generally depended upon. In a portion of the PSBs in India, the act of selecting masters, for example, specialized workers, administration students and so on specifically from the presumed organizations through grounds interviews have been begun. A few banks are likewise using the administrations of advisors and work on contract premise.

\section{Preparing and Development}

HRD as one of the major useful region in HRM. Proceeding with instruction and preparing projects are basic contemplations to improve their professions and exceed expectations their advancement. Saving money exercises and learning is regularly evolving. Keeping in mind the end goal to adapt up to these progressions and to build up representatives' professions all banks set up their own particular preparing foundation. Those organizations sorted out various sorts of preparing and advancement programs in light of the representatives require. Those necessities are distinguished by need appraisal exercises.

Preparing is more in IPSBs in light of the fact that the preparation framework in the saving money industry has a solid basic base, and has abilities to deal with preparing in huge numbers. The framework has likewise built up a few imaginative exercises in the preparation territory, for example, on-area preparing, supervisor to emissary programs. Facilitate the IPSBs have a decent support to preparing endeavors from zenith level preparing establishments, for example, National Institute of Bank Management (NIBM), Bankers Training College (BTC), and College of Agricultural Banking (CAB). The IPSBs have more than three hundred individual bank level preparing universities and preparing focuses.

Preparing is given accentuation by all banks, in spite of the fact that very little orderly preparing need investigation is done. The preparation schools direct preparing programs for moderately junior level bank staff. For the majority of the senior level preparing, banks rely on upon outside offices, particularly remote preparing associations. Preparing foundations of a portion of the greater banks gripe of under usage.

\section{Execution Appraisal}

Execution examination is the methodical, occasional and an unprejudiced rating of the representative's magnificence in matters relating to his present employment and of his possibilities for a superior job.(Edwin B. Flipp). Open Sector Banks in India give more consideration towards execution evaluation in the associations. Execution examination in view of nature of yield, capability of the representative inside the association and so forth should be fused over all review, frameworks and levels. This won't just guarantee expanding efficiency, additionally go far in inspiring star entertainers adjusting to the long haul mission and vision of banks.

Pay

All in all, the remuneration in Public Sector banks is for the most part in light of rank or work understanding. The Indian open segment banks ought to remunerate their professionally qualified workers by scale up-degree and unique augmentations other than propelling and urging them to obtain new information. Basic pay structures in light of number of years of administration with the bank put in and so forth should be eliminated in an arranged way.

\section{Indian Commercial Banking System}

The Indian Commercial Banking System incorporates the planned business banks and the local provincial banks which work in rustic zones. The present creation of Indian business saving money framework can be delegated:

(A) Public Sector Banks:

(a) SBI (State Bank of India and its 7 Associate Banks)

(b) 19 Nationalized Banks

(c) RRB's (Regional Rural Banks, supported by Public Sector Banks)

These banks work under the top money related expert, viz., Reserve Bank of India. The names of these banks are as per the following:

Open division business banks are (a) State Bank of India and its seven Associates Banks (1)State Bank of Bikaner and Jaipur (2)State Bank of Hyderabad (3)State Bank of Indore (4)State Bank of Mysore (5)State Bank 
of Patiala (6)State Bank of Saurashtra (7)State Bank of Travancore (b) Nationalized Banks are (Out of 20 Banks, one Bank 'New Bank of India' converged with Punjab National Bank in 1992-93 coming about into 19 Nationalized Banks) (1)Allahabad Banks (2)Andhra Bank (3)Bank of Baroda (4)Bank of India (5)Bank of Maharashtra (6)Canara Bank (7) Central Bank of India (8)Corporation Bank (9)Dena Bank (10)Indian Bank (11)Indian Overseas Bank (12)Oriental Bank of Commerce (13) Punjab and Sind Bank (14)Punjab National Bank (15)Syndicate Bank (16)UCO Bank (17)Union Bank of India (18)United Bank of India (19) Vijaya Bank (c) Regional Rural Banks

(B) Private Sector Banks:

(a) Old private segment banks (21 in number)

(b) New private segment banks (9 in number)

(c) Foreign banks working in India (27 Banks)

New private segment banks are (1)Bank of Punjab Ltd. (2)Centurion Bank Ltd. (3)Global Trust Bank Ltd. (4)HDFC Bank Ltd. (5)ICICI Bank Ltd. (6)IDBI Bank Ltd. (7)Indusind Bank Ltd. (8)Kotak Mahindra Bank Ltd. (9)UTI Bank Ltd.

Remote Bank Working in India are (1)ABN Amro Bank N.V. (2)Abu Dhabi Commercial Bank Ltd. (3) American Express Bank Ltd. (4)Arab Bangladesh Bank Ltd. (5)Bank International Indonesia (6)Bank of America NA (7)Bank of Bahrain and Kuwait BSC (8)Barclays Bank PLC (9)BNP Paribas (10)Calyon Bank Citibank N.A. (11)Deutsche Bank AG (12)ING Bank N.V. (13)JP Morgan Chase Bank (14)Krung Thai Bank Public Company Ltd. (15)Marshreg Bank PSC (16)MIZUHO Corporate Bank Ltd. (17)Oman International Bank SAOG (18)Societe Generale (19)Sonali Bank (20)Standard Chartered Bank (21)State Bank of Mauritius (22)Sumitomo Mitsui Banking Corporation (23)The Bank of Nova (24)Scotia (25)The Bank of Tokyo Mitsubishi Ltd. (26)The Development Bank of Singapore Ltd. (27)The Hong-Kong and Shanghai BKG Corpo. Ltd.

\section{Recommendations}

On the premise of survey of this review the accompanying recommendations are improved for HRM hone in the Public part banks in India:

- In the enlistment and determination procedure of representatives, the banks ought to offer need to the applicants who has graduate or more degrees in Information Technology, encounter, aptitudes, capabilities and so forth. It is likewise proposed that institutional preparing ought to give successful aptitudes to worker. Workers ought to be persuaded to use the material and libraries with the goal that competency hole would be decreased.

- It is fundamental for rebuilding of pay to propel workers in especially openly segment banks.

- To create HR, the bank ought to attempt diverse human asset advancement programs including proceeding with instruction and preparing, IT-introduction, vocation improvement, and so forth.

- Banks can send brilliant representatives to another country on cooperation/grant for higher reviews and learn new innovation with a specific end goal to achieve fitness at worldwide level.

- Banks ought to sort out classes, workshops, meetings, diverse short courses, and preparing programs on money related matters, current issues, programming up degree on consistent premise that would create educated labor, make mindfulness and change mental dispositions among the experts.

- All banks ought to distribute adequate spending plan and sends capable workers to universal gatherings and workshops to set them up for the focused learning worldwide market.

- Human Resource Department is basic to enable the office or divisions for dealing with various issues in HRM in banks. The divisions ought to be fused with efficient human asset data frameworks and present day data innovation offices.

- Public division banks ought to every now and again welcome staff for recommendations and their dynamic interest in gatherings keeping in mind the end goal to empower and staff fulfillment.

- The preparation universities direct preparing programs for generally junior level bank staff. For the majority of the senior level preparing, banks rely on upon outer offices, particularly remote preparing associations. It is to better to use of greater banks preparing foundations notwithstanding for senior level as opposed to relying upon outside offices or remote associations.

- It is recommended that worker potential ought to be assessed in light of target evaluation however not on preference. Straightforwardness in assessment and advancement approach additionally recommended. 


\section{Conclusion}

The achievement of banks to a great extent relies on upon the scholarly advancement of the representatives. Alongside scholarly advancement of the information laborer, specialized frameworks of the bank must be guaranteed to upgrade the adequacy of the worker and the bank. The Public division banks need to take start to change in their HRM approaches and rehearses, so as to contend with private/outside banks in present situation. Bank ought to decentralize their HR exercises in all branches and create solid HR polices. Specialist and duty ought to be legitimately conveyed to all HR supervisors. Bank ought to give some huge power and part to HR chief so as to engage the HR divisions. This will select and keep up gifted, learned and very much performed workforce to meet present and future authoritative and also singular needs. From now on, people in general segment banks in India need to use numerous chances to meet certain difficulties under the changed situation. Considering the present element worldwide business condition, the present paper for the most part centered around the current framework in saving money area in India, open segment banks need to seek after more supported HRM hones.

\section{References}

[1]. Karishma, Gulati and Shikha N. Khera, Role of HR Practices and KM Tools in knowledge-sharing behavior of Internal Customers at Commercial Banks in Delhi, The IUP Journal of Bank Management, Vol.XII, No.2, 2013 |

[2]. Mangaleswaran.T and Srinivasan.P.T, A Comparative Study of Human Resource Management Practices in Sri Lakan and Indian Public Sector Banks, |

[3]. Vandana Gautam and B.S.Bhatia, Coperative Banks and Global Financial Crisis, , Indian Streams Research Journal, Vol-1, Issue-V, June 2011.

[4]. Garima Shrivastava and Gupta P.K., HR Practices: A comparative study of public and private sector banks in Indore, |

[5]. Mathivanan P, A study on HRM Practices in Public Sector Banks in Krishnagiri District, iosrjournals. Volume 12, Issue-4, Nov Dec, 2013. |

[6]. Ramu N, Human resource management in cooperative banks in india: Issues and challenges, CAB CALLING, July-september |

[7]. Shilpi Singh, Face of HR Practices in Todays Scenario in Indian Banks,IJAIEM, Volume 2, Issue 1, January 2012 |

[8]. www.rbi.org| 